\title{
Hybrid Solar - Wind - Diesel Systems for Rural Application in North Ethiopia: Case Study for Three Rural Villages using HOMER Simulation
}

\author{
Alfa Hailemariam Abraha ${ }^{1}$, Mulu Bayray Kahsay ${ }^{2 *}$ and Cuthbert Z.M. Kimambo ${ }^{3}$ \\ ${ }^{1}$ Mechanical Engineering, Energy and Environmental Management; University of Flensburg, \\ Germany (alpha_hailemariam@yahoo.com) \\ ${ }^{2}$ Department of Mechanical Engineering, Ethiopian Institute of Technology (EiT-M),Mekelle \\ University, Mekelle, Ethiopia (*mul_at@yahoo.com) \\ ${ }^{3}$ Mechanical and Industrial Engineering Department, University of Dar es Salaam, Tanzania \\ (kimambo@udsm.ac.tz)
}

\begin{abstract}
This paper considers the feasibility of developing Solar (photovoltaic)-Wind-Diesel hybrid power systems for supplying electricity to off-grid rural communities in the Tigray region of northern Ethiopia. Using wind resource assessment and solar potential-based data from the National Meteorological Agency of Ethiopia, a case study of three sites in Tigray is presented Serawet (645 households), Feleg Daero (338 households) and Adi Mesanu (55 households) which typify, respectively, large, medium and small off-grid communities. The energy demand was determined through a field survey and previous historical data of similar villages electrified through grid extension. The Hybrid Optimization Model for Electric Renewables (HOMER) was used to simulate and generate feasible solution through combinations of photovoltaic, Wind Turbines and Diesel Generators with a minimum levelised cost of electricity. The simulations indicate that a hybrid system option, compared to a diesel only system, is feasible for each of the three villages.
\end{abstract}

Keywords: Hybrid, HOMER, Photovoltaic, Wind energy, Solar energy, Rural electrification, Tigray, Ethiopia.

\section{INTRODUCTION}

In most developing countries electrifying rural households by extending the main grid is a major challenge due to economic and technical reasons. There is a need therefore to find other methods of supplying electricity to rural households. Supply of electricity to rural communities will have significant impact on preventing problems associated with deforestation, environmental effects and contributing towards sustainable development.

Like several other developing countries, Ethiopia is characterized by dependence on traditional biomass and most significantly, severe modern energy shortage in rural areas where more than $80 \%$ of the population of the country lives. Access to electricity is one of the lowest in Africa. Despite current efforts to increase access, many communities will not be reached for some years to come. On the other hand, Ethiopia is one of the countries endowed with renewable energy 
resources such as hydro, solar, wind and geothermal. Thus, renewable energy sources are options for off-grid electricity supply in the country. The northern part of the country where the study focuses on has high Solar and Wind energy potential. It is expected that hybrid Solar - Wind energy systems with diesel backup will provide good possibilities due to the complementary nature of the resources in the area.

This paper therefore demonstrates this fact by presenting a study made on hybrid Solar - Wind Diesel systems in three rural villages in the Tigray region of Northern Ethiopia, namely Serawat, Feleg Daero and Adi Mesanu; tries to demonstrate the feasibility of Solar-Wind-Diesel based hybrid systems for electrifying rural communities; and determine optimum configurations for the three sites.

\subsection{Literature Review}

\subsubsection{Solar Energy Resource Assessment}

Previous studies on solar energy resource assessment of the country include Neway (1996), Yacob and Frances (1996), Addis Ababa University (AAU) (2001), and Solar and Wind Energy Resource Assessment (SWERA) (2007). The study by Neway (1996) compared the measurement of global solar radiation with corresponding calculated values using Angestrom's relations. The regression coefficients were obtained and the correlation equations were determined to predict the global solar radiation. The results show that Angestrom's relations are valid for the locations under study. Yacob and Frances (1996) used sunshine hour records from 21 meteorological stations in the country to illustrate the general availability of the resource. The report by AAU indicated that the annual average daily solar radiation ranges from $4.25 \mathrm{kWh} / \mathrm{m}^{2}$ to $6.25 \mathrm{kWh} / \mathrm{m}^{2}$. Solar radiation maps of the country produced based on satellite data by SWERA (2007)also indicate that the country has significant solar radiation potential.

\subsubsection{Wind Energy Resource Assessment}

The first study reported on Wind energy potential of the country was by Welde Ghiorgis (1988). The study was based on wind speed data obtained from meteorological observations. The study shows estimates of the expected energy and explains reasons for expecting the calculated energy estimates to be potentially useful. Later studies include Yacob and Frances (1996) and SWERA (2007). Yacob and Fraces (1996) used wind and solar data from 21 meteorological stations and previous studies to illustrate the wind and solar energy potential across the country and SWERA 
(2007) came up with a map of wind and solar energy potential in the country.

\subsubsection{Hybrid Systems}

Studies made on hybrid system for Ethiopia are scarce. A study made by RENAC (2008) on feasibility of photovoltaic (PV)-diesel hybrid system for Ethiopia favored the PV-diesel hybrid system despite the high investment cost of the hybrid system. Another study made on the feasibility of solar - wind based hybrid system was reported by Bekele and Palm (2010). This study assessed the solar and wind energy potential for four locations in Ethiopia. HOMER software was employed to make the analysis for a model community of 200 households. However, the study concluded that the diesel power scheme (i.e. $100 \%$ diesel) was more feasible option than the solar-wind-diesel set up.

\section{DESCRIPTION OF THE STUDY SITES}

\subsection{Geographical Data of the Sites}

The current study has been conducted for three specific villages in North Ethiopia, in Enderta and Atsbi-Womberta Woredas of Tigray Region. The villages discussed here in this paper are: Serawat, Feleg Daero and Adi Mesanu. Other villages were part of the master's thesis study by Abraha (2011). Table 1 summarizes the geographical data of the villages. The three villages are models for large, medium and small size communities.

Table 1. Geographical data of the sites.

\begin{tabular}{|lllll|}
\hline Village Name & Longitude & Latitude & Altitude $(\boldsymbol{m})$ & No. of Households \\
\hline Serawat & $39.53 \mathrm{E}$ & $13.47 \mathrm{~N}$ & 2221 & 645 \\
\hline Feleg Daero & $39.47 \mathrm{E}$ & $13.52 \mathrm{~N}$ & 2001 & 338 \\
\hline Adi Mesanu & $39.74 \mathrm{E}$ & $13.88 \mathrm{~N}$ & 2511 & 55 \\
\hline
\end{tabular}

\subsection{Energy Demand Profile}

Energy demands of the population in the villages are for lighting, cooking, water pumping, milling cereals and refrigeration in health clinics. The load profile for the respective villages was determined by field survey and observing previous trends of similar villages recently electrified. The information for electrified villages and towns was obtained from the Ethiopian Electric Power Corporation (2010). The survey of the villages of the current study was conducted to determine the number of households, number of rooms per household and other energy demand 
in the villages. The survey determined the lighting load, cooking load, energy needed to replace diesel operated water pumps, milling stations and energy demand of health clinics. Figure 1 shows the load profile of the villages. The peak load is from 18.00-24.00 hours due to the expected significant lighting load in the households.

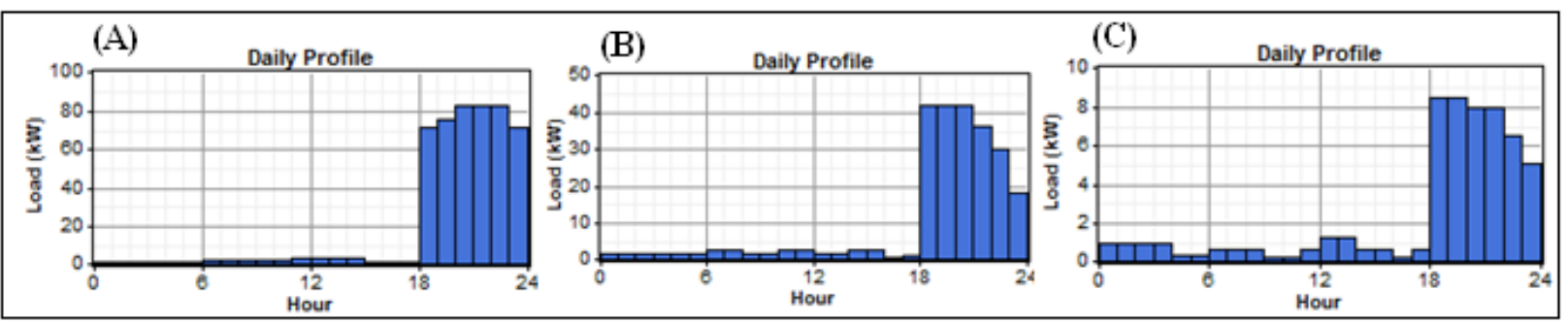

Figure 1. Load Profile for Serawat (A), Feleg Daero (B), Adi Mesanu (C).

Table 2. Summary of the load profiles for the sites

\begin{tabular}{|lllll|}
\hline Village Name & $\begin{array}{l}\text { Average Daily } \\
\text { Demand }(\boldsymbol{k W h})\end{array}$ & $\begin{array}{l}\text { Average Power } \\
(\boldsymbol{k W})\end{array}$ & $\begin{array}{l}\text { Peak Power } \\
(\boldsymbol{k W})\end{array}$ & Load Factor \\
\hline Serawat & 497 & 20.7 & 146 & 0.14 \\
\hline Feleg Daero & 238 & 9.9 & 74 & 0.13 \\
\hline Adi Mesanu & 55 & 2.3 & 14.9 & 0.15 \\
\hline
\end{tabular}

To account for the day to day and hour to hour variability, $15 \%$ and $20 \%$ variability respectively, was introduced to the average daily load profiles shown in figure 1 which resulted in higher peak power demand. A summary of the load profiles after the variability has been applied to the average load for all the three villages is shown in table 2 . The power demand has a low load factor as shown in table 2 and is characterized by low energy demand during the day time and peak demand during the evening. This is because of the fact that electricity is primarily used for lighting application and the lack of commercial and industrial demand in the villages.

\subsection{Solar Energy Resource}

The most common solar energy resource data collected in many of the meteorological stations throughout the country is the average daily sunshine hours. The available sunshine hour data from the National Meteorological Agency of Ethiopia (2010) was used to estimate the solar energy resource of the sites. Figure 2 shows the eight years average daily sunshine hours in each month for the sites under study. 


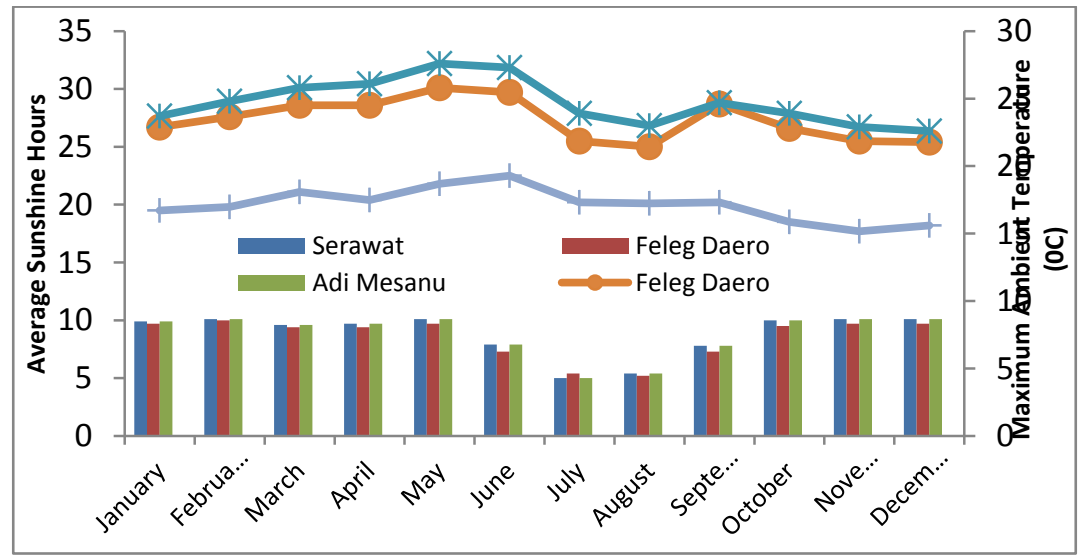

Figure 2. Average Sunshine Hours and Maximum Temperature.

\subsection{Wind Energy Resource}

Wind energy data are measured at $2 \mathrm{~m}$ above ground in many meteorological stations in Ethiopia though wind speed measurements at $10 \mathrm{~m}$ are available at some airports and are more useful for predicting Wind Turbine power. Even though recently wind energy resource assessment for power generation has been conducted at some sites, the available data for these sites during the period of this study was $2 \mathrm{~m}$ data from the National Meteorological Agency (2010). Thus eight year monthly average wind speed data measured at $2 \mathrm{~m}$ was used for the resource assessment, with subsequent extrapolation to $10 \mathrm{~m}$ values. Data under collection at Ethiopian Institute of Technology-Mekelle University (EiT-M) at 10m was considered for comparison purposes (Mulu, 2011).

\section{METHODOLOGY}

\subsection{Modeling Daily Solar Radiation}

The sunshine hour data available has been converted to monthly average daily global solar radiation, $H_{G}$, from $\mathrm{H}_{0}$, the monthly average daily extraterrestrial radiation, employing theAngestrom - Page estimation model(Duffie and Beckman, 1980), given by Equation 1.

$H_{G}=H_{o}\left(a+b \frac{n}{N}\right)$

Where

$\mathrm{H}_{\mathrm{G}}$ ismonthly average daily global solar radiation

$\mathrm{H}_{\mathrm{O}}$ is monthly average daily extraterrestrial solar radiation

a is Angestrom's correlation parameter

(c) CNCS, Mekelle University 
b is Angestrom's correlation parameter

$\mathrm{n}$ is monthly average daily hours of sunshine from sunshine recorder

$\mathrm{N}$ is monthly average of the maximum possible hours of sunshine

$\mathrm{H}_{\mathrm{o}}$ is determined based on the Solar Constant, average day of the month and the declination angle. The values for $\mathrm{N}$, $\mathrm{a}$ and $\mathrm{b}$ were determined using Equations 2, 3 and 4.

$\mathrm{N}=\frac{2}{15} \cos ^{-1}(-\tan \Phi \tan \delta)$

$a=-0.309+0.539 \cos \Phi-0.0693 E o+0.290\left(\frac{n}{N}\right)$.

$b=1.527-1.027 \cos \Phi+0.0926 E o-0.359\left(\frac{n}{N}\right)$

Where

Eo is Altitude of a site in kilometers

$\delta$ is declination angle for the average day in the month

$\alpha$ is Hellman coefficient

$\Phi$ is Latitude of the site

\subsection{Wind Speed Profile}

The wind speed data available as discussed in section 3 is measurement data at $2 \mathrm{~m}$. Such a measurement has its own limitation since it is prone to shading by buildings and vegetation. However, it can be used in the absence of other data by making use of wind shear effects. The plot of the $2 \mathrm{~m}$ monthly average data is shown in figure 3 .

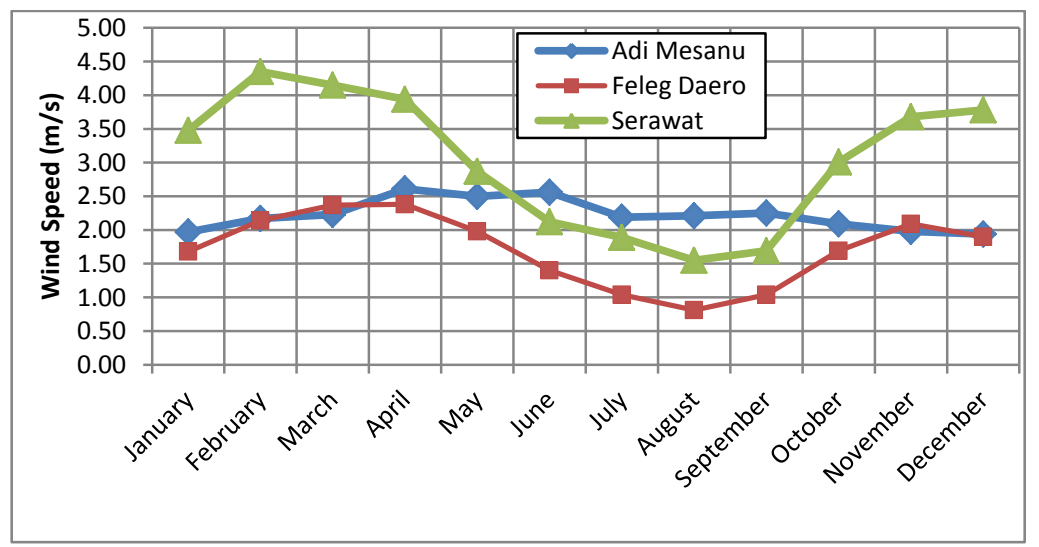

Figure 3. Wind Speed at $2 \mathrm{~m}$ height from Meteorological Stations.

The Hellman exponential law also known as the Power law is used here to find the wind speed at turbine hub height from the data at $2 \mathrm{~m}$ as given in Equation 5 . 


$$
\frac{\mathrm{V}_{\mathrm{Z}}}{\mathrm{V}_{\mathrm{Z} \text { ref }}}=\left[\frac{\mathrm{z}}{\mathrm{z}_{\mathrm{ref}}}\right]^{\alpha}
$$

The Hellman coefficient $\alpha$ can be computed by the empirical formula given in Equation 6

$\alpha=0.096 \log _{10} \mathrm{Z}_{\mathrm{o}}+0.016\left(\log _{10} \mathrm{Z}_{\mathrm{o}}\right)^{2}+0.24$

Where

$\mathrm{V}_{\mathrm{Z}}$ is mean wind speed at height $\mathrm{Z}$

$V_{\text {zref }}$ is mean wind speed at the reference height of the study terrain

$\mathrm{Z} \quad$ is study height above the ground

$\mathrm{Z}_{\mathrm{ref}}$ is reference height, $2 \mathrm{~m}$

$\mathrm{Z}_{0} \quad$ is surface roughness length

Zo value ranges $0.001 \mathrm{~m}<\mathrm{Zo}<10 \mathrm{~m}$ and the surface roughness for the sites was considered in the range of few trees $(\mathrm{Zo}=0.1)$ to many trees and few buildings $(\mathrm{Zo}=0.25)$. Therefore, the average Helleman coefficient of $\alpha=0.2$ was used in the calculations.

\subsection{Hybrid Modeling in HOMER}

HOMER software has been used for the modeling, analysis and optimization. The software takes solar energy and wind energy data; models PV, wind turbine, diesel generator and batteries with different sizes to match the demand; makes economic analysis considering costs of components. Optimization is based on Levelized Cost of Electricity (LCOE) which is defined as the ratio of the sum of the levelized annual cost to the annual electricity production of the system. The system with the least LCOE meeting the power demand of the village is considered to be the optimized option.

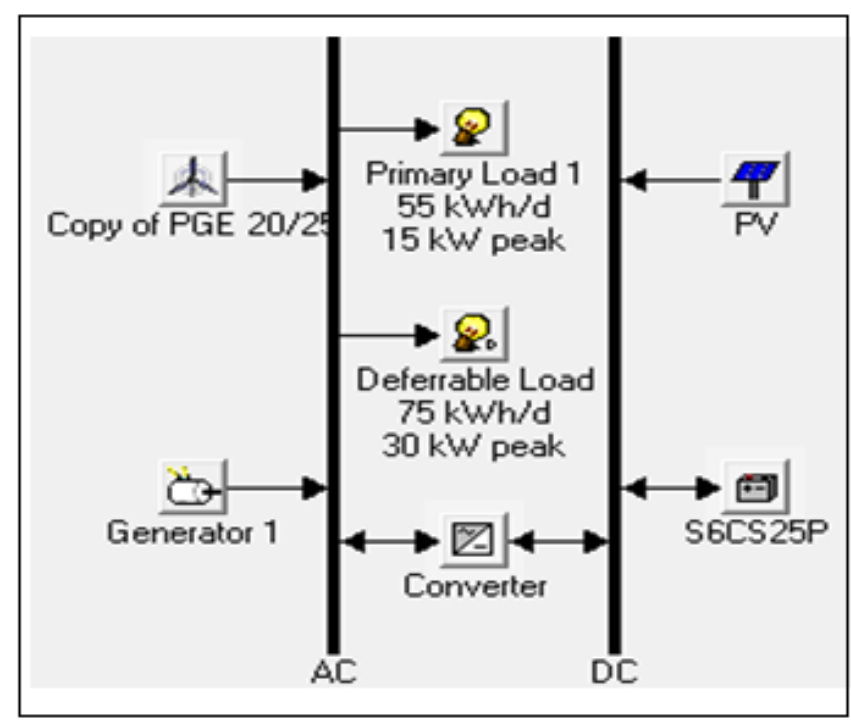

Figure 4. A HOMER Model Representation of a Parallel Hybrid System. 
The hybrid system modeled in this study for each village consists of PV, wind turbine, diesel generator as power sources. The system also includes battery storage and inverter. The type of the hybrid system modeled is a parallel hybrid system. The parallel system has an alternating current (AC) and direct current (DC) buses as shown in figure 4. The wind turbine and the generator with $\mathrm{AC}$ power sources are connected to the AC bus. The PV and battery are connected to the DC bus. The parallel system was selected compared with series or switched system for its advantage of higher overall efficiency and avoiding double conversion of electricity from AC to DC and vice versa.

Among the physical properties of the diesel generator which are required as input to HOMER include power output capacity, expected life time in operating hours and fuel consumption. In addition, economic parameters such as capital cost, replacement cost, operation and maintenance cost are required. A synchronous type alternator directly coupled to the diesel engine is selected. The efficiency of the generator is assumed to be $35-45 \%$. Since the fuel consumption depends on the operating power, fuel consumption at part load was included in the modeling to account for the decreased efficiency when the generator is not working at full load. To avoid very low efficiency operation the minimum load ratio for the generator is taken to be $40 \%$.Capital costs of $\$ 32,500, \$ 28,829$ and $\$ 23,283$ were used for high speed generators of $180 \mathrm{~kW}, 100 \mathrm{~kW}$ and $45 \mathrm{~kW}$ capacity for Serawat, Feleg Daero and Adi Mesanu respectively. Life time of 15,000 running hours has been considered. The combined operating and maintenance cost of the diesel generators, which takes in to account the operating costs, maintenance costs and future price uncertainties, is $\$ 65 / \mathrm{hr}$, $\$ 37.5 / \mathrm{hr}$ and $\$ 18.1 / \mathrm{hr}$ for Serawat, Feleg Daero and Adi Mesanu respectively.

Due to its low cut-in wind speed, ease of transportation and erection, appropriate rated capacity and cost, the PGE25 wind turbine with a rated capacity of $25 \mathrm{~kW}$ AC and manufactured by PGE Energy of Canada has been selected for the analysis. The capital cost of the wind turbine including electrical components, foundation, erection and other site activities is $\$ 42,250$ with an annual operation and maintenance cost of $\$ 2,499$. The technical specifications of the wind turbine are given in table 3.

Typical specifications were also taken for the PV modules. The efficiency of the PV modules was assumed to be $13 \%$ with nominal operating temperature of $47^{0} \mathrm{C}$. The temperature 
coefficient of power was considered to be $-0.5 \% /{ }^{0} \mathrm{C}$ and a life of 25 years. The capital cost for small scale PV systems is higher than for large scale applications and the costs related to distribution and transportation are expected to have an impact in this case. Thus a capital cost of $\$ 4000 / \mathrm{kW}$ and an annual operation and maintenance cost of $\$ 20 / \mathrm{kW}$ has been considered.

Table 3. Technical specifications of the PGE25 wind turbine.

\begin{tabular}{|ll|}
\hline Parameter & Values \\
\hline Rated Power & $25 \mathrm{~kW} \mathrm{AC}$ \\
\hline Available Tower Heights & $20 / 30 / 36$ meters \\
\hline Selected Tower Height & 36 meters \\
\hline Rotor Diameter & 20 meters \\
\hline Swept Area & $305 \mathrm{~m}^{2}$ \\
\hline Rotational Speed & $32 \mathrm{rpm}$ \\
\hline Cut in Wind Speed & $3.5 \mathrm{~m} / \mathrm{s}$ \\
\hline High Wind Speed Cut out & $25 \mathrm{~m} / \mathrm{s}$ \\
\hline Low Wind Speed Cut out & $1.7 \mathrm{~m} / \mathrm{s}$ \\
\hline
\end{tabular}

To optimize the system for better performances, create a buffer for engine start ups, provide system stability and store excess electricity generated from PV panels for later uses; batteries have also been considered as part of the modeled system. A Surette 6CS25P battery with a nominal capacity of $1156 \mathrm{Ah}$ and Nominal voltage of $6 \mathrm{~V}$ was used as an input for the simulation. To avoid losses and reduce conductor sizes a system bus voltage of $48 \mathrm{~V}$ has been chosen. Thus, there are 8 batteries per string (8x6) which result in $48 \mathrm{~V}$. A capital cost of $\$ 833$ and annual operation and maintenance cost of $\$ 15$ have been used as economic parameters for the battery.

An AC/DC bidirectional converter is also required to convert the DC electricity from the PV panels and the batteries to feed the AC loads as well as charge the batteries from the excess AC electricity produced by the diesel generator and wind-turbine. The AC/DC inverter used in the modeling has an efficiency of $85 \%$ in the rectifier mode and $90 \%$ in the inverter mode. Life time of 10 years and a capital cost of $\$ 700$ have been used.

The last sets of economic inputs parameters used are the interest rate, diesel fuel price and the prevailing exchange rates from Ethiopian Birr (ETB) to USD used at the time of the study. A 9\% interest rate, 16.37 ETB/ 1 \$ exchange rate and diesel fuel price of \$0.98/liter was used according to data obtained from the National Bank of Ethiopia and the Ministry of Trade. 


\section{RESULTS AND DISCUSSION}

This section shows the results of the solar and wind resource analysis, the optimization and simulation of the system on HOMER and presents the discussion of the outputs of the optimization model.

\subsection{Results from the Estimation Model of Solar Radiation}

The Angstrom estimation model discussed in section 4 was used to find the monthly average daily global solar radiation by using input data such as latitude, altitude, the average day in the month, the declination angle for the day and the sunshine hour data. A worksheet was created with all the input data for each month and employing Equations $1-4$ the parameters $\mathrm{N}, \mathrm{a}, \mathrm{b}, \mathrm{H}_{0}$ and finally $\mathrm{H}_{\mathrm{G}}$ were calculated. The worksheet for Serawat is shown in Annexure 1 as a sample. Monthly clearness index defined as the ratio of solar radiation received on the earth's surface to the extraterrestrial radiation $\left(\mathrm{H}_{\mathrm{G}} / \mathrm{H}_{\mathrm{o}}\right)$ has been calculated for each site as well. The results of the estimation model indicate very close values for the solar radiation in the three sites. This is due to the fact that the sites are located close to each other and there is only a slight variation in the altitude of the sites. The average daily global solar radiation varies from around 5.0 $\left(\mathrm{kWh} / \mathrm{m}^{2} /\right.$ day $)$ in rainy month of July to just above $7.0\left(\mathrm{kWh} / \mathrm{m}^{2} /\right.$ day $)$ in the dry months. Similarly the clearness index varies from the lowest value of 0.5 in July to the highest value of 0.67 in most of the months of the year. Thus, according to Kudish and Ianetz (1996), the three sites can be classified as clear sky for most times of the year and partially cloudy during the rainy season.

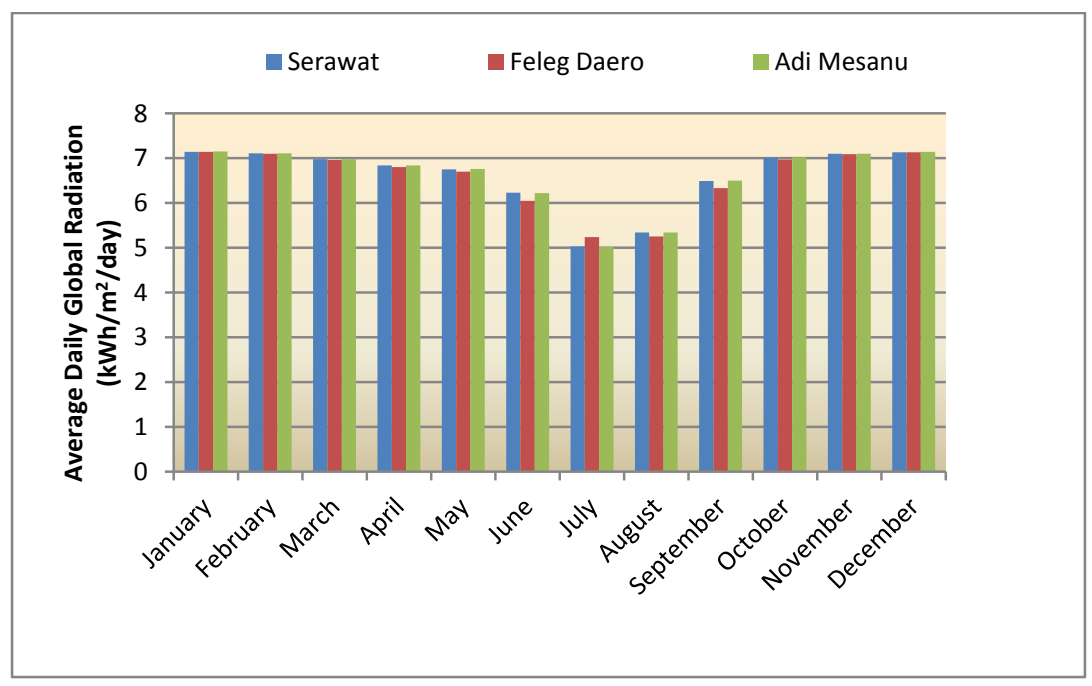

Figure 5. Calculated Global Solar Radiation for each month. 
The final calculated results of the monthly average daily global solar radiation $\mathrm{H}_{\mathrm{G}}$ is shown in figure 5. The monthly average daily global solar radiation $\mathrm{H}_{\mathrm{G}}$ has been used as an input for the HOMER analysis.

\subsection{Results from the Wind Resource Data Analysis}

The wind speed data at $2 \mathrm{~m}$ height from the National Meteorology Agency is shown in table 4 . The data at $2 \mathrm{~m}$ height was extrapolated to wind speed data at 10 mbased on the Hellman exponential law presented in Equation 5. The extrapolation result at $10 \mathrm{~m}$ is shown in figure 6. The site at Serawat has relatively higher wind speed with a significant seasonal variation. The wind speed varies from around $2 \mathrm{~m} / \mathrm{s}$ in August to around $6 \mathrm{~m} / \mathrm{s}$ in February. Adi Mesanu has low wind speed resource with wind speeds of around $3 \mathrm{~m} / \mathrm{s}$ showing no significant seasonal variation. Among the three sites Feleg Daero showed low wind speed varying from $1 \mathrm{~m} / \mathrm{s}$ in August to slightly above $3 \mathrm{~m} / \mathrm{s}$ in March again with significant seasonal variations. The wind speed data at $2 \mathrm{~m}$ and wind shear coefficient of 0.2 were used as input data for the HOMER analysis. HOMER extrapolates the $2 \mathrm{~m}$ data to the hub height of the turbine considered which is $36 \mathrm{~m}$.

Table 4. Average Wind speed in $\mathrm{m} / \mathrm{s}$ at $2 \mathrm{~m}$ height from NMA.

\begin{tabular}{|llllllllllll|}
\hline $\begin{array}{l}\text { Village } \\
\text { Name }\end{array}$ & January & February & March & April & May & June & July & August & September October December \\
\hline Serawat & 3.48 & 4.35 & 4.15 & 3.94 & 2.87 & 2.12 & 1.89 & 1.55 & 1.69 & 3.01 & 3.78 \\
\hline $\begin{array}{l}\text { Feleg } \\
\text { Daero }\end{array}$ & 1.68 & 2.14 & 2.37 & 2.38 & 1.98 & 1.4 & 1.04 & 0.81 & 1.04 & 2.09 & 1.9 \\
\hline $\begin{array}{l}\text { Adi } \\
\text { Mesanu }\end{array}$ & 1.97 & 2.17 & 2.23 & 2.61 & 2.5 & 2.56 & 2.19 & 2.21 & 2.25 & 1.98 & 1.94 \\
\hline
\end{tabular}

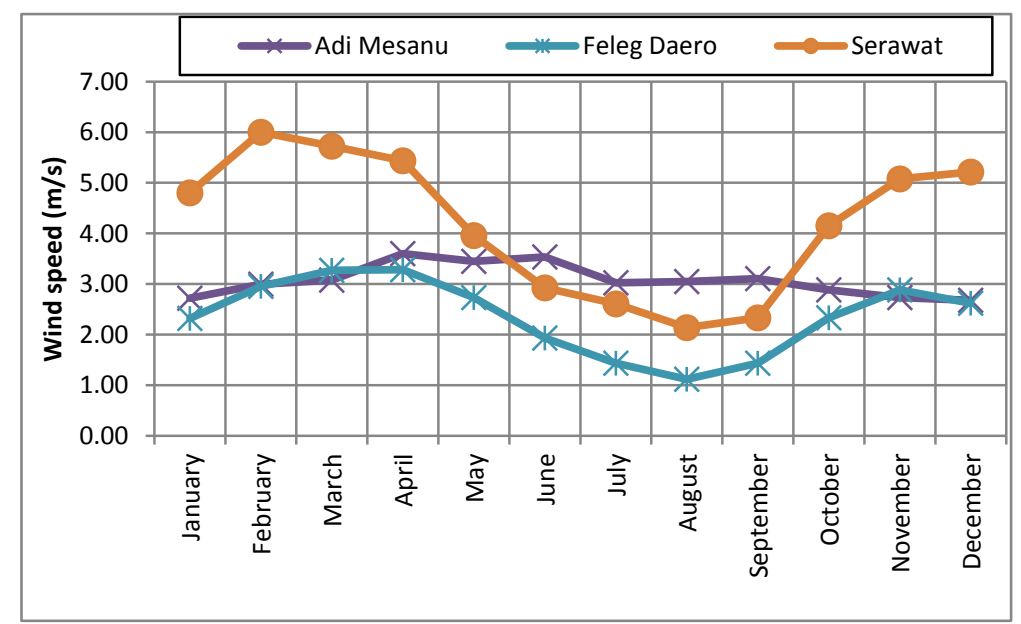

Figure 6. Extrapolated Wind Speed Data at $10 \mathrm{~m}$. 
To check the accuracy of the extrapolation, the result of the data for Serawat was compared with data being measured at EiT-M (Mulu, 2011) to determine the correlation between those two data sets. Even though slight differences in the absolute value of the results exist, a correlation analysis resulted in a correlation coefficient of 0.92 which indicated that there is a strong relationship between the two data sets. The monthly averages of the wind data measurement at EiT-M and the extrapolated data for Serawat are show in figure 7.

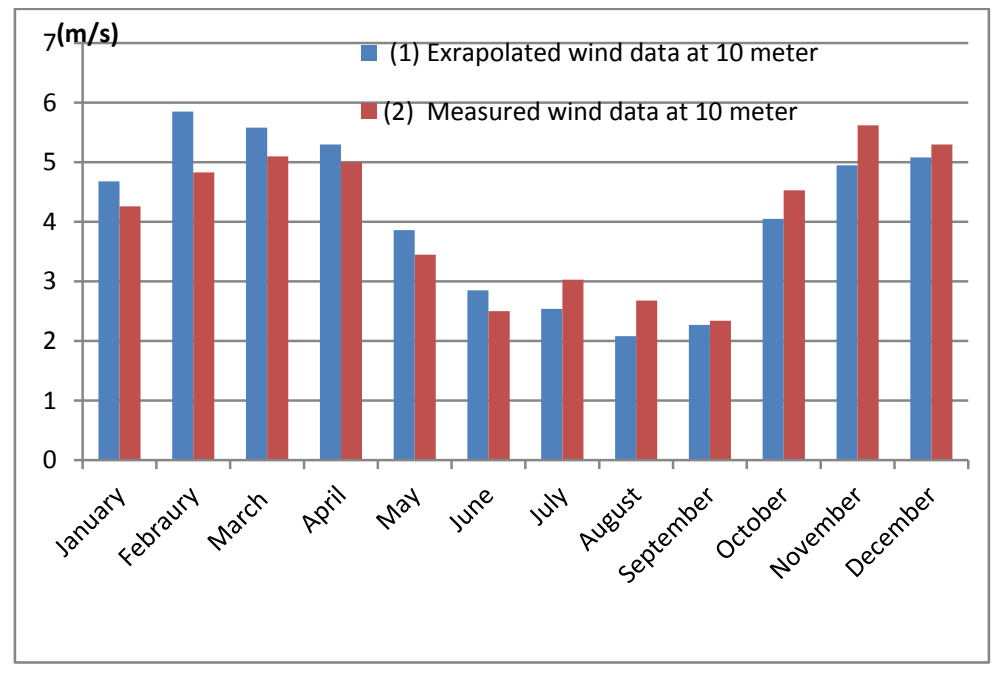

Figure 7. Measured and Extrapolated Monthly Average Wind Speeds, Serawat.

As can be seen from figure 7 the extrapolated data resulted in slightly higher values than the measured wind speed data for the months January to June where as in the months July to December the extrapolated average wind speeds are slightly lower than the measured values.

\subsection{Results from the Hybrid System Analysis and Optimization using HOMER}

HOMER software models were created for conducting the analysis. Based on the load profile discussed in section 3 appropriate sizes and numbers of equipments to be considered were selected for each site. The necessary energy resource inputs from solar and wind were supplied fromthe results discussed in previous sub-sections 4.1 and 4.2. The equipment representation of the hybrid systems for Serawat, Feleg Daero and Adi Mesanu are shown in figure 8(A), (B) and (C) respectively. The equipment configuration of the three sites is similar, the only difference being on the capacity of the primary and deferrable loads.

The results of the optimization in HOMER for the sites are discussed in the subsequent sections. In each case a table showing a listing of selected feasible system options is given (Tables 5-7). 
Amongst the options, the table shows system architectures for the least cost system, 100\% renewable penetration system and $100 \%$ diesel option. Similarly, for each case a figure showing electricity production contribution of each technology on a monthly basis is given (Figures 9-10).
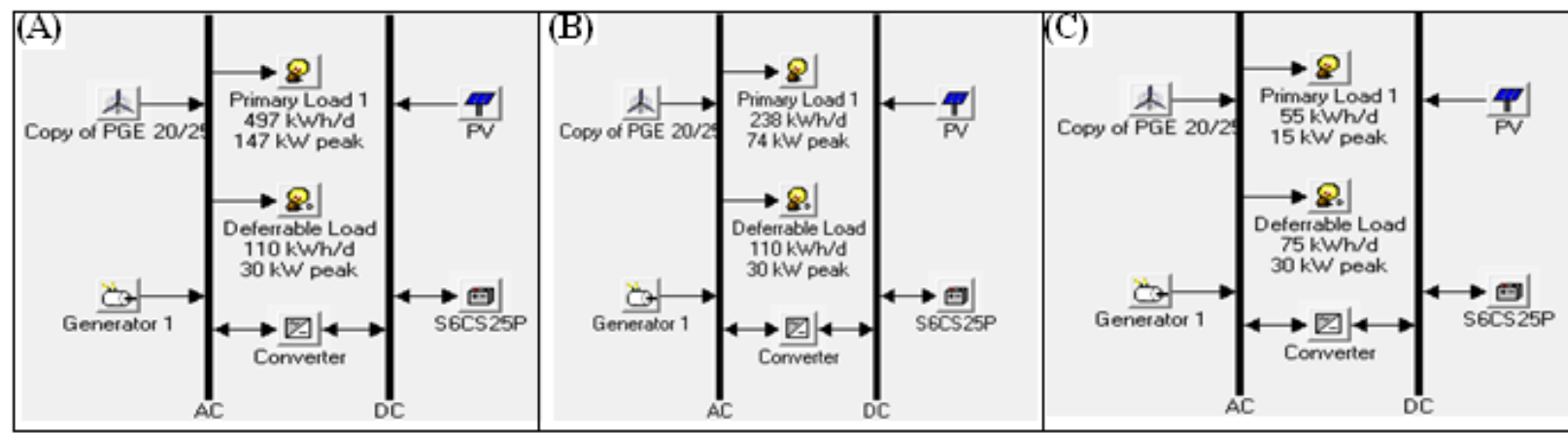

Figure 8. Equipment Representations of the Hybrid Systems, (A) Serawat, (B) Feleg Daero, and (C) Adi Mesanu.

\subsubsection{Serawat}

A summary of the optimization results in a categorized form for Serawat has been presented in table 5. The least cost option for this site is the wind-diesel option. This is primarily because of the good wind resource of the site and the cheaper price per installed capacity of the wind turbine as compared to PV. Figure 9 shows the share of average monthly electricity production by the wind turbine and the diesel generator. As can be seen from the figure 9 the diesel generator is used as back up in most of the months in the year, supplying less than $10 \%$ of total energy generated except in the months June to September, where a larger proportion of the produced energy comes from the diesel generator.

Table 5. Categorized optimization results for Serawat according to net present cost.

\begin{tabular}{|c|c|c|c|c|c|c|c|c|c|}
\hline $\begin{array}{l}P V \\
(k W)\end{array}$ & $\begin{array}{l}\text { Number } \\
\text { of Wind } \\
\text { Turbines }\end{array}$ & $\begin{array}{l}\text { Diesel } \\
\text { Generator } \\
(k W)\end{array}$ & $\begin{array}{l}\text { No. of } \\
\text { Batteries }\end{array}$ & $\begin{array}{l}\text { Converter } \\
(k W)\end{array}$ & $\begin{array}{l}\text { Total Capital } \\
\text { Cost }(\$)\end{array}$ & $\begin{array}{l}\text { Total Net } \\
\text { Present } \\
\text { Cost }(\$)\end{array}$ & $\begin{array}{l}\text { LCOE } \\
(\$ / k W h)\end{array}$ & $\begin{array}{l}\text { Renewable } \\
\text { Fraction }\end{array}$ & $\begin{array}{l}\text { Diesel } \\
\text { Consum- } \\
\text { ption } \\
(\text { L/Year })\end{array}$ \\
\hline 0 & 5 & 110 & 240 & 100 & 501,031 & $1,248,119$ & 0.574 & 0.86 & 17,507 \\
\hline 5 & 5 & 110 & 240 & 100 & 521,031 & $1,253,599$ & 0.576 & 0.87 & 16,898 \\
\hline 180 & 0 & 70 & 400 & 150 & $1,170,839$ & $1,526,634$ & 0.702 & 0.94 & 5,767 \\
\hline 180 & 3 & 0 & 560 & 130 & $1,404,230$ & $1,733,954$ & 0.797 & 1.00 & 0 \\
\hline 0 & 0 & 150 & 0 & 0 & 27,083 & $6,161,842$ & 2.831 & 0 & 137,797 \\
\hline
\end{tabular}




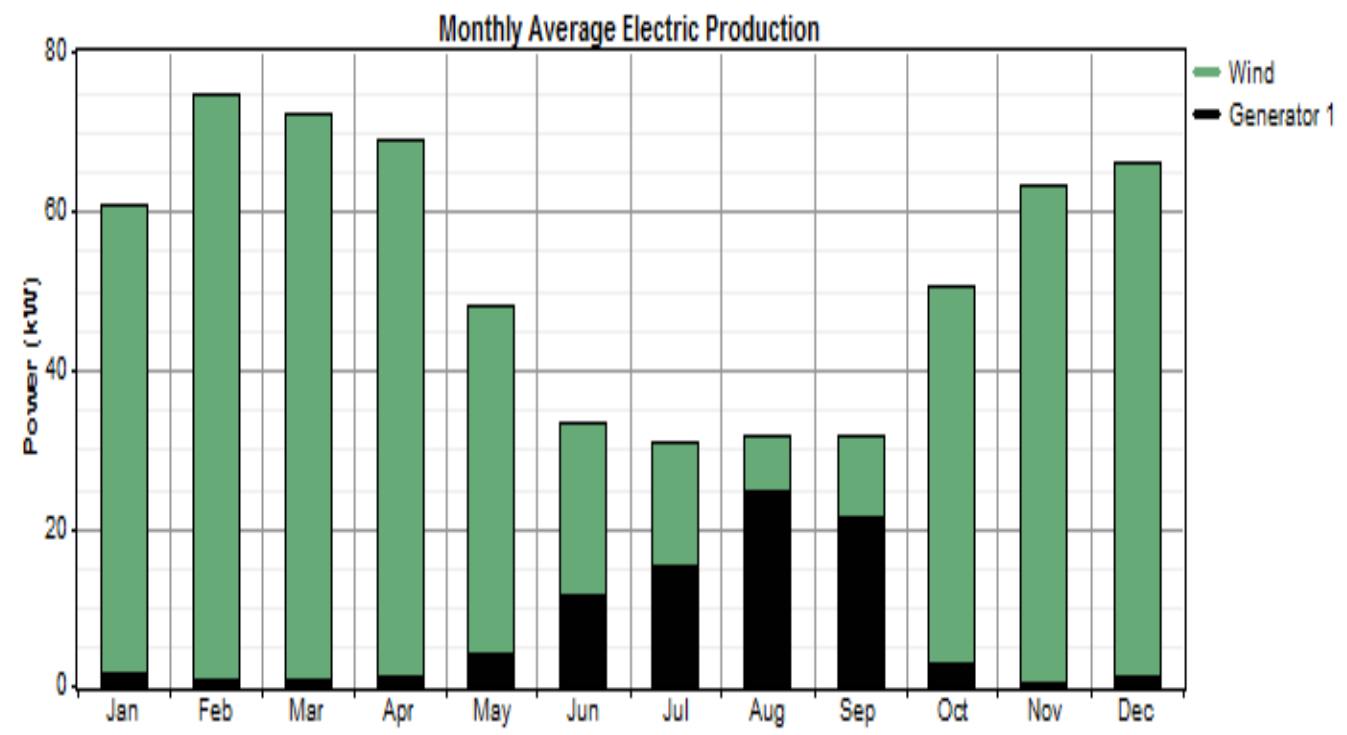

Figure 9. Power Shares of Components for the Optimal Wind-Diesel System at Serawat.

The least cost wind-diesel hybrid option for this site has 5 Wind Turbines and a $110 \mathrm{~kW}$ diesel generator, with a Levelized Cost of Electricity (LCOE) of $0.574 \$ / \mathrm{kWh}$. To attain a $100 \%$ renewable option, $180 \mathrm{~kW} \mathrm{PV,} 3$ wind turbines and a battery bank should be combined which raises the LCOE to $0.702 \$ / \mathrm{kWh}$. The last row of table 5 shows the $100 \%$ diesel option which will have a significantly higher LCOE of $2.83 \$ / \mathrm{kWh}$.

\subsubsection{Feleg Daero}

Similarly, the optimization results for Feleg Daero site are shown in table 6. The least cost option for this site is the PV-wind-diesel option. As in the previous case the diesel generator is used as back up except for the months June to September where PV and wind could not supply the required energy.

Table 6. Categorized optimization results for feleg Daero according to net present cost.

\begin{tabular}{|c|c|c|c|c|c|c|c|c|c|}
\hline $\begin{array}{l}P V \\
(k W)\end{array}$ & $\begin{array}{l}\text { Number of } \\
\text { Wind } \\
\text { Turbines }\end{array}$ & $\begin{array}{l}\text { Diesel } \\
\text { Generator } \\
(k W)\end{array}$ & $\begin{array}{l}\text { Number } \\
\text { of } \\
\text { Batteries }\end{array}$ & $\begin{array}{l}\text { Converter } \\
(\mathrm{kW})\end{array}$ & $\begin{array}{l}\text { Total Capital } \\
\text { Cost }(\$)\end{array}$ & $\begin{array}{l}\text { Total Net } \\
\text { Present } \\
\text { Cost }(\$)\end{array}$ & $\begin{array}{l}L C O E \\
(\$ / k W h)\end{array}$ & $\begin{array}{l}\text { Renewable } \\
\text { Fraction }\end{array}$ & $\begin{array}{l}\text { Diesel } \\
\text { Consum- } \\
\text { ption } \\
\text { (L/Year) }\end{array}$ \\
\hline 30 & 2 & 50 & 120 & 50 & 353,875 & 754,408 & 0.605 & 0.85 & 11,299 \\
\hline 0 & 3 & 50 & 160 & 70 & 323,445 & 766,324 & 0.614 & 0.85 & 13,092 \\
\hline 100 & 0 & 30 & 200 & 70 & 624,249 & 886,466 & 0.711 & 0.91 & 5,991 \\
\hline 100 & 2 & 0 & 320 & 90 & 814,060 & $1,030,860$ & 0.827 & 1.00 & 0 \\
\hline 0 & 0 & 85 & 0 & 0 & 24,505 & $3,758,776$ & 3.012 & 0 & 89,144 \\
\hline
\end{tabular}




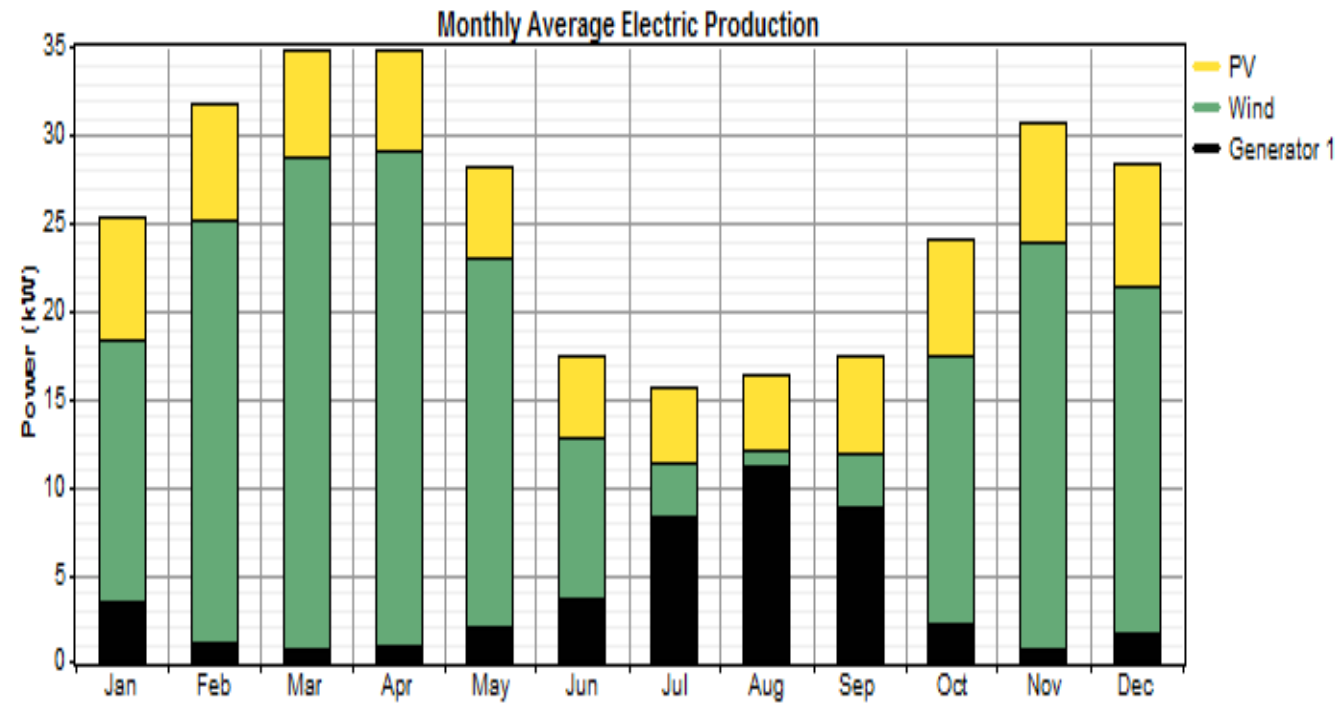

Figure 10. Power Shares of Components for the Optimal PV-Wind-Diesel System, Feleg Daero.

Figure 10 shows the average monthly electricity production of each component. The LCOE for this system is $0.605 \$ / \mathrm{kWh}$, with $30 \mathrm{~kW} \mathrm{PV}$, two Wind-Turbines and $50 \mathrm{~kW}$ Diesel Generator. In the $100 \%$ renewable penetration option, the LCOE increases to $0.827 \$ / \mathrm{kWh}$. In the case of a $100 \%$ diesel supply indicated in the last row of Table 6 the LCOE surges to $3.012 \mathrm{USD} / \mathrm{kWh}$.

\subsubsection{Adi Mesanu}

The results for Adi Mesanu also show similar results to that of Serawat and Feleg Daero. The optimization results for Adi Mesanu site have been summarized in table 7. The least cost option for this site is PV-Wind-Diesel option with more wind penetration. Figure 11 shows the contribution of each technology towards the monthly electricity production and it can be observed that the diesel generator is used as a backup for most of the months throughout the year, though it makes its biggest contributions in January and December.

Table 7. Categorized optimization results for Adi mesanu according to net present cost.

\begin{tabular}{|c|c|c|c|c|c|c|c|c|c|}
\hline \begin{tabular}{|l|}
$P V$ \\
$(k W)$
\end{tabular} & $\begin{array}{l}\text { Number o } \\
\text { Wind } \\
\text { Turbines }\end{array}$ & $\begin{array}{l}\text { fDiesel } \\
\text { Generator } \\
(k W)\end{array}$ & $\begin{array}{l}\text { Number } \\
\text { of } \\
\text { Batteries }\end{array}$ & $\begin{array}{l}\text { Converter } \\
(\mathrm{kW})\end{array}$ & $\begin{array}{l}\text { Total } \\
\text { Capital } \\
\text { Cost (\$) }\end{array}$ & $\begin{array}{l}\text { Total N } \\
\text { Present } \\
\text { Cost }(\$)\end{array}$ & $\begin{array}{l}\text { et LCOE } \\
\quad(\$ / k W h)\end{array}$ & $\begin{array}{l}\text { Renewable } \\
\text { Fraction }\end{array}$ & $\begin{array}{l}\text { Diesel } \\
\text { Consum- } \\
\text { ption } \\
(\text { L/Year }) \\
\end{array}$ \\
\hline 5 & 1 & 10 & 32 & 10 & 101,081 & 191,580 & 0.410 & 0.90 & 2,184 \\
\hline 0 & 1 & 10 & 32 & 10 & 81,081 & 198,261 & 0.425 & 0.84 & 3,377 \\
\hline 15 & 1 & 0 & 80 & 15 & 179,390 & 241,049 & 0.517 & 1.00 & 0 \\
\hline 0 & 0 & 15 & 0 & 0 & 7,762 & 781,317 & 1.673 & 0 & 22,009 \\
\hline
\end{tabular}

(C) CNCS, Mekelle University $76 \quad$ ISSN:2220-184X 


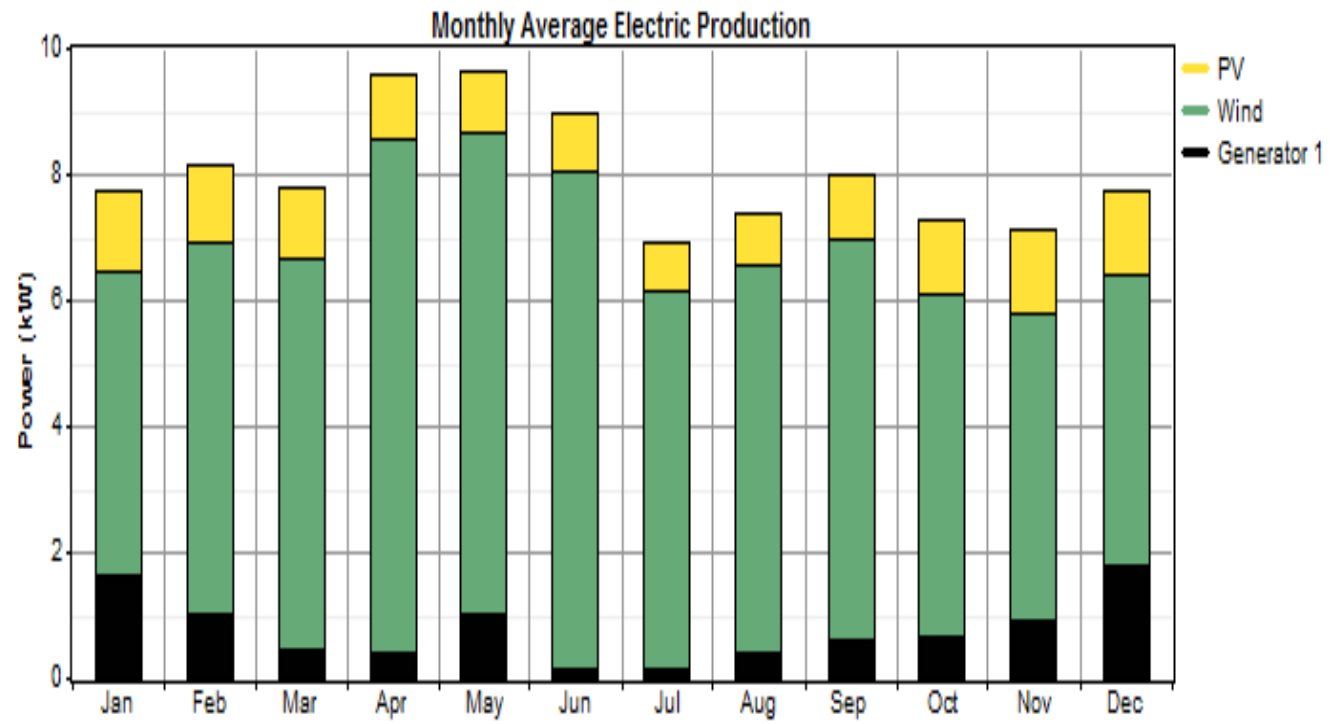

Figure 11. Power Shares of Components for the Optimal PV-Wind-Diesel System, Adi Mesanu.

Due to increased penetration of wind and PV production as compared to the optimal systems from the other sites resulting in reduced running hours of the diesel generator the LCOE of this hybrid system is the lowest of the three sites at $0.410 \$ / \mathrm{kWh}$. The LCOE for the $100 \%$ renewable option and $100 \%$ diesel option are $0.517 \$ / \mathrm{kWh}$ and $1.673 \$ / \mathrm{kWh}$ respectively.

\section{CONCLUSION}

Like many other parts of the country the Northern part of Ethiopia is characterized by low electrification rate in rural areas, dependence on fuel wood and dung for cooking. Kerosene is widely used in wick lamps and hurricane lamps in areas where there is no access to electricity. Despite the extensive rural electrification scheme being carried out, due to the dispersed nature of the rural settlements and low energy demands it will be difficult to reach out to every corner through grid extension.

This paper has thus presented an option of rural electricity supply through Solar-Wind-Diesel hybrid systems. It has been shown that the three sites taken as a case study have limited wind resource. Even though the sites have an excellent solar resource the optimal system configurations obtained through simulation in HOMER have higher wind penetration than PV due to higher capital costs for PV. Due to the continued reduction in PV module prices, PV could also be a major component in the hybrid systems in the area. Though the levelized cost of (C) CNCS, Mekelle University 
electricity from the hybrid systems demonstrated in this study is highly comparable to the subsidized electricity price in the country; it is significantly lower than a diesel only electricity supply. This will bring major advantages by alleviating incidents related to indoor pollution, encouraging small scale productive activities and reducing burden on the country's economy by replacing imported fuel.

\section{ACKNOWLEDGMENTS}

The authors would like to thank the National Meteorological Agency of Ethiopia (NMA) and the Ethiopian Electric Power Corporation (EEPCo) for providing data used in the study. The authors would also like to thank NOMA for providing financial support. The comments and suggestions provided by the reviewers Dr. Dilip, Dr. Venkatesan and Dr. John Paintin are highly appreciated and duly acknowledged.

\section{REFERENCE}

Abraha, A. H., 2011. Hybrid Solar-Wind-Diesel Systems for Rural Application in North Ethiopia. M.Sc thesis, University of Dar es Salaam, Tanzania.

Addis Ababa University (AAU), 2001. Renewable Energy Resource and Technologies. Final Report, V. II, Electrical and Computer Engineering Department, Addis Ababa University, Addis Ababa, Ethiopia.

Bekele, G \& Palm, B., 2010. Feasibility Study for a Stand Alone Solar-Wind Based Hybrid Energy System for Application in Ethiopia. Applied Energy, 87:487-495.

Duffie, A. J \& Beckman, A.W. 1980. Solar Engineering of Thermal Processes, Wiley and Sons Inc., New York, pp. 68-76.

Ethiopian Electric Power Corporation (EEPCo.) 2010. Northern Region Distribution Systems, Universal Electricity Access Program customer power demand and network diagrams (unpubl.).

Kudish, A. I \& Ianetz, A. 1996. Analysis of Daily Clearness Index, Global and Beam Radiation for Beer Sheva, Israel: Partition According to Day Type and Statistical Analysis. Energy Conversion and Management, 37(4):405-416. 
Alfa Hailemariam, A., Mulu Bayray, K and Cuthbert Z.M. K (MEJS) Volume 5(2):62-80, 2013

Mulu Bayray, Anwar Mustefa, Hailay Kiros \& others. 2011. Wind and Solar Energy Resource Assessment in Geba Catchment, North Ethiopia. Annual Report, Department of Mechanical Engineering, Ethiopian Institute of Technology, Mekelle University, Ethiopia, pp. 3-16.

National Meteorological Agency of Ethiopia. 2010. Meteorological Stations data archive (unpubl.).

Neway, A. 1996. Estimation of Solar Radiation Energy of Ethiopia from Sunshine Data. International Journal of Sustainable Energy, 18(2):103-113.

Renewable Energy Academy (RENAC). 2008. Off-grid Power Supply Through Photovoltaics. Berlin, Germany, pp. 16-19.

Solar and Wind Energy Resource Assessment (SWERA). 2007. Solar and Wind Energy Utilization and Project Development Scenarios. Final Report, Ethiopian Rural Energy Promotion and Development Center, Addis Ababa, Ethiopia, p. 3-1 - 3-13.

Welde Ghiorgis, W. 1988. Wind Energy Survey in Ethiopia. Solar and Wind Technology, 5(4):341-351, 1988.

Yakob, M \& Frances, D. 1996. Assessment of Wind and Solar Energy in Ethiopia. Solar energy, 57(4):323-334. 
Alfa Hailemariam, A., Mulu Bayray, K and Cuthbert Z.M. K(MEJS) Volume 5(2):62-80, 2013

Annexure.1. Sample worksheet for solar resource calculations of Serawat.

\begin{tabular}{|c|c|c|c|c|c|c|c|c|c|c|c|c|c|}
\hline $\begin{array}{l}\text { Site } \\
\text { Name }\end{array}$ & Parameter & 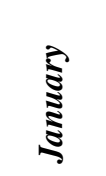 & 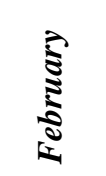 & $\frac{\sqrt{3}}{2}$ & $\frac{\sqrt{4}}{\sqrt[5]{2}}$ & हे & $\underset{\mathfrak{z}}{\mathfrak{z}}$ & $\vec{\Xi}$ & $\frac{\sqrt{1}}{3}$ & 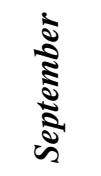 & $\frac{5}{0}$ & $\begin{array}{l}\grave{\Xi} \\
\vdots \\
\vdots \\
\vdots \\
\vdots\end{array}$ & 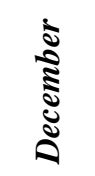 \\
\hline \multirow{10}{*}{$\begin{array}{l}\text { Serawat } \\
\Phi=13.47 \\
\mathrm{E}_{0}=2.22\end{array}$} & $\begin{array}{l}\text { Average sunshine } \\
\text { hours } \mathrm{n} \text { from Table } 3\end{array}$ & 9.9 & 10.1 & 9.6 & 9.7 & 10.1 & 7.9 & 5.0 & 5.4 & 7.8 & 10.0 & 10.1 & 10.1 \\
\hline & $\begin{array}{l}\text { The day length of the } \\
\text { average day of the } \\
\text { month } N \text { (hours) } \\
\text { Figure 2 }\end{array}$ & 11.31 & 11.58 & 11.93 & 12.31 & 12.63 & 12.79 & 12.72 & 12.45 & 12.08 & 11.70 & 11.38 & 11.23 \\
\hline & $\begin{array}{l}\text { The percent possible } \\
\text { sun shine }\left(\frac{n}{N}\right)\end{array}$ & 0.87 & 0.87 & 0.80 & 0.79 & 0.80 & 0.62 & 0.40 & 0.43 & 0.65 & 0.86 & 0.89 & 0.90 \\
\hline & $\begin{array}{l}\text { Inclination angle for } \\
\text { the average day of the } \\
\text { month } \delta \text { (Degrees) }\end{array}$ & -20.9 & -13.0 & -2.4 & 9.4 & 18.8 & 23.1 & 21.2 & 13.5 & 2.2 & -9.6 & -18.9 & -23.0 \\
\hline & \multirow{2}{*}{\begin{tabular}{l|l} 
Coefficients & $\mathrm{a}$ \\
A\& b are & \\
$\begin{array}{l}\text { calculated from } \\
\text { Equation } 3 \& 4\end{array}$ & $\mathrm{~b}$ \\
\end{tabular}} & 0.31 & 0.31 & 0.29 & 0.29 & 0.29 & 0.24 & 0.18 & 0.19 & 0.25 & 0.31 & 0.32 & 0.32 \\
\hline & & 0.42 & 0.42 & 0.45 & 0.45 & 0.45 & 0.51 & 0.59 & 0.58 & 0.50 & 0.43 & 0.41 & 0.41 \\
\hline & $\begin{array}{l}\text { Average number of the } \\
\text { day in the month }\end{array}$ & 17 & 47 & 75 & 105 & 135 & 162 & 198 & 228 & 258 & 288 & 318 & 344 \\
\hline & Hour angle $\omega_{\mathrm{s}}$ (Degrees) & 84.80 & 86.88 & 89.47 & 92.32 & 94.72 & 95.91 & 95.37 & 93.34 & 90.57 & 87.73 & 85.34 & 84.21 \\
\hline & $\begin{array}{l}\text { Monthly Average daily } \\
\text { extraterrestrial } \\
\text { radiation } \mathrm{H}_{0}\left(\mathrm{kWh} / \mathrm{m}^{2}\right)\end{array}$ & 10.71 & 10.16 & 10.79 & 10.14 & 10.59 & 10.75 & 10.73 & 10.19 & 10.62 & 10.37 & 10.29 & 10.63 \\
\hline & $\begin{array}{l}\text { Monthly Average daily } \\
\text { global radiation, } \mathrm{H}_{\mathrm{G}} \\
\left(\mathrm{kWh} / \mathrm{m}^{2}\right) \text { Equation } 1 . \\
\text { Monthly Average Clear- } \\
\text { ness Index }\left(\mathrm{H}_{\mathrm{G}} / \mathrm{H}_{0}\right)\end{array}$ & 7.14 & 7.11 & 6.98 & 6.84 & 6.75 & 6.23 & 5.03 & 5.34 & 6.49 & 7.01 & 7.10 & 7.13 \\
\hline
\end{tabular}

